\title{
Psoriasisban szenvedö betegek életminőségének vizsgálata Magyarországon
}

\author{
Poór Adrienn Katalin dr. ${ }^{1}$ - Sárdy Miklós dr. ${ }^{1}$ - Cserni Tamás ${ }^{2,3}$ \\ Brodszky Valentin dr. ${ }^{2}$ - Holló Péter dr. ${ }^{1}$ - Gulácsi László dr. ${ }^{2}$ \\ Remenyik Éva dr. ${ }^{4}$. Szegedi Andrea dr. ${ }^{4,5}$. Rencz Fanni dr. ${ }^{* 2,6}$ \\ Péntek Márta dr. ${ }^{* 2}$
}

\begin{abstract}
${ }^{1}$ Semmelweis Egyetem, Általános Orvostudományi Kar, Bőr-, Nemikórtani és Bőronkológiai Klinika, Budapest Budapesti Corvinus Egyetem, ${ }^{2}$ Egészségügyi Közgazdaságtan Tanszék, ${ }^{3}$ Közgazdaságtudományi Kar, Budapest Debreceni Egyetem, Általános Orvostudományi Kar, Bőrgyógyászati Klinika, ${ }^{4}$ Bőrgyógyászati Tanszék,

${ }^{5}$ Bőrgyógyászati Allergológiai Tanszék, Debrecen

${ }^{6}$ MTA Prémium Posztdoktori Kutatói Program, Budapest
\end{abstract}

Bevezetés: Magyarországon a psoriasisos betegpopuláció egészségi állapota és életminősége kevéssé ismert.

Célkituzés: Kutatásunk célja a hazai psoriasisos betegek életminőségének vizsgálata és összehasonlítása az általános populációval, illetve az életminőséget befolyásoló tényezők azonosítása.

Módszer: 2012 és 2016 között két keresztmetszeti kérdőíves felmérést végeztünk két hazai egyetemi klinika psoriasisos betegeinek bevonásával. Az életminőséget az EQ-5D-3L és a hozzá tartozó Vizuális Analóg Skála (EQ VAS), valamint a Bőrgyógyászati Életminőség Index (DLQI) segítségével vizsgáltuk. Az életminőséget befolyásoló tényezőket többváltozós lineáris regresszióval elemeztük.

Eredmények: A kérdőívet 434 psoriasisos beteg töltötte ki (átlagéletkor 49 év, 65\% férfi, 81\% középsúlyos vagy súlyos psoriasis). A felmérés időpontjában a betegek 43\%-a biológiai terápiában részesült. A mintában az EQ-5D-3L, az EQ VAS és a DLQI átlaga $0,74 \pm 0,28,69,06 \pm 20,98$, illetve $6,78 \pm 7,38$ volt. A fájdalom/rossz közérzet, szorongás/lehangoltság, mozgékonyság, szokásos tevékenységek és önellátás dimenziókban rendre a betegek $54,43,40$, 32 és 15 százaléka jelzett problémát. Az EQ-5D-3L-index alapján a betegek életminősége rosszabb volt, mint a nemben és korban illesztett általános populációé, a különbség férfiaknál a 25-34 és 45-64 éves korcsoportokban, illetve nőknél a 18-64 éves korcsoportban volt statisztikailag szignifikáns $(\mathrm{p}<0,05)$. Szignifikánsan rosszabb volt a nők $(\mathrm{p}=0,042)$, az arthritis psoriaticás $(\mathrm{p}<0,001)$ és a tenyéri/talpi psoriasisos $(\mathrm{p}=0,031)$ betegek életminósége. Jobb életminőséget találtunk a felsőfokú végzettségű és a teljes vagy részmunkaidőben foglalkoztatott betegeknél $(\mathrm{p}<0,001)$.

Következtetések: Kutatásunk az első kiterjedt életminőség-felmérés az EQ-5D-kérdőívvel psoriasisos betegek körében Magyarországon és tágabban egész Közép-Kelet-Európában. Az eredmények hasznosak lehetnek a psoriasis terápiáinak költséghatékonysági modellezésében, illetve egészségpolitikai döntések elókészítésében. Orv Hetil. 2018; 159(21): 837-846.

Kulcsszavak: psoriasis, egészséggel összefüggő életminőség, EQ-5D, DLQI, Magyarország

\section{Assessment of health-related quality of life in psoriasis patients in Hungary}

Introduction: The health status and health-related quality of life (HRQoL) of patients with psoriasis in Hungary are understudied.

Aim: To assess HRQoL in psoriasis patients, to compare HRQoL of psoriasis patients to that of the general public in Hungary and to identify predictors of HRQoL.

Method: Between 2012 and 2016, two cross-sectional surveys were carried out among psoriasis patients at two academic dermatology departments. HRQoL was assessed by EQ-5D-3L, EQ Visual Analogue Scale (EQ VAS) and Dermatology Life Quality Index (DLQI). Predictors of HRQoL were analysed by multivariate linear regression. Results: 434 patients were enrolled (mean age 49 years, 65\% male, 81\% moderate-to-severe psoriasis, $43 \%$ treated with biologics). Mean EQ-5D-3L, EQ VAS and DLQI scores were 0.74 $\pm 0.28,69.06 \pm 20.98$ and $6.78 \pm 7.38$,

*A szerzők megosztott utolsó szerzőként egyenlő mértékben járultak hozzá a közlemény elkészítéséhez. 
respectively. Overall, $54 \%, 43 \%, 40 \%, 32 \%$ and $15 \%$ of patients indicated at least some problems in pain/discomfort, anxiety/depression, mobility, usual activities and self-care. EQ-5D-3L index scores in patients were lower compared to the age- and gender-matched general population in Hungary. The difference was statistically significant for the age groups 25-34 and 45-64 in males, and 18-64 in females $(\mathrm{p}<0.05)$. Female gender $(\mathrm{p}=0.042)$, psoriatic arthritis $(\mathrm{p}<0.001)$ and palmoplantar psoriasis $(\mathrm{p}=0.031)$ were associated with lower EQ-5D-3L index scores. On the contrary, employed and highly educated patients reported higher EQ-5D-3L index scores $(\mathrm{p}<0.001)$.

Conclusions: We were the first to assess HRQoL in psoriasis patients by using EQ-5D questionnaire in Hungary, and more broadly in Central and Eastern Europe. Our findings are useful for cost-effectiveness modelling of psoriasis treatments and decision-making in healthcare.

Keywords: psoriasis, health-related quality of life, EQ-5D, DLQI, Hungary

Poór AK, Sárdy M, Cserni T, Brodszky V, Holló P, Gulácsi L, Remenyik É, Szegedi A, Rencz F, Péntek M. [Assessment of health-related quality of life in psoriasis patients in Hungary]. Orv Hetil. 2018; 159(21): 837-846.

(Beérkezett: 2018. január 1.; elfogadva: 2018. február 13.)

\begin{abstract}
Rövidítések
BSA $=($ Body Surface Area $)$ a testfelszín százalékban kifejezett értéke; DLQI = (Dermatology Life Quality Index) Bőrgyógyászati Életminőség Index; EQ-5D = (EuroQol Group 5 Dimensions) Egészségi Állapot Kérdőív; EQ VAS = (EuroQol Group Visual Analogue Scale) Vizuális Analóg Skála; NEAK = Nemzeti Egészségbiztosítási Alapkezelő; PASI = (Psoriasis Area and Severity Index) Psoriasis Kiterjedési és Súlyossági In$\operatorname{dex} ;$ PUVA $=($ psoralen and ultraviolet $\mathrm{A})$ psoralen és UVA sugárzás; $\mathrm{SD}=$ standard deviáció
\end{abstract}

A psoriasis (pikkelysömör) az egyik leggyakoribb krónikus bő́rgyógyászati betegség, felnőtttkori prevalenciája 0,51-11,43\% közötti, előfordulását az életkor és a földrajzi régió is meghatározza $[1,2]$. Az immunmediált gyulladás kialakításában a genetikai prediszpozíció mellett a környezeti tényező́k is szerepet játszanak $[3,4]$. A plakkos formában a parakeratoticus bőrtünetek jellemzően a fejtető, a könyök, a térd és a glutealis régió felett jelennek meg, azonban középsúlyos és súlyos esetekben testszerte nagyobb bőrfelületet érinthetnek. Szövődményes esetben az egész bőrfelszín inflammatiója felléphet (erythroderma psoriaticum). Emellett klasszikusan megkülönböztetünk még guttált, inverz és pustulosis psoriasis formákat [5]. A betegek harmadában ízületi gyulladás, arthritis psoriatica jelentkezik, melyet funkcionális limitáció, jelentős fájdalom és ízületi destrukció jellemez [6]. További terhet jelentenek a komorbiditások, a metabolikus szindróma, a hypertonia, a diabetes mellitus, a hyperlipidaemia, az obesitas, a cardiovascularis betegségek és a májfibrosis, melyek kialakulásának kockázata psoriasisban fokozott [7-10]. A psoriasis bőrtünetei nagymértékben ronthatják a betegek egészséggel összefüggő életminőségét (a továbbiakban: életminőség) [11]. A fizikai tünetek mellett sokszor pszichoszociális problémák is jelentkeznek [12, 13].

Az európai konszenzus szerint a psoriasis súlyosságát három klinikai mérce alapján definiálhatjuk, ezek a Psoriasis Area and Severity Index (PASI), a Bőrgyógyászati Életminőség Index (Dermatology Life Quality Index,
DLQI) és a Body Surface Area (BSA), mely a testfelszín százalékban kifejezett értékét jelenti [14]. Ez alapján a (PASI $\leq 10$ vagy $B S A \leq 10$ ) és $D L Q I \leq 10$ enyhe, míg a (PASI>10 vagy $B S A>10$ ) és $D L Q I>10$ középsúlyos vagy súlyos psoriasist jelent, melyben szisztémás kezelés javasolt, azonban a 2015-ös, európai S3-irányelv értelmében a psoriasisra jellemző tulajdonságok (látható tünetek, kiterjedt fejbőri tünetek, genitális érintettség, legalább két körmöt érintő onycholysis vagy onychodystrophia, vakaráshoz vezetó viszketés, makacs plakkok) fennállása esetén az enyhe esetek felértékelődnek, a középsúlyos vagy súlyos kategóriába kerülnek $[14,15]$. A hazai plakkos psoriasis finanszírozási protokollja értelmében enyhe-középsúlyos eseteknél $(\mathrm{PASI}<15$ vagy $\quad \mathrm{BSA}<10)$ és DLQI<10, lokális kezelés, ennek eredménytelensége esetén szisztémás nem biológiai terápia adható (methotrexat, retinoid, ciclosporin) [16]. Súlyos eset kapcsán (PASI $\geq 15$ vagy $B S A \geq 10$ ) és DLQI $\geq 10$, szisztémás kezelés indítása indokolt, ennek sikertelensége esetén biológiai terápia indikálható [16].

A psoriasisos betegek száma hazánkban eléri a 150 000-200 000 föt, közülük 2015-ben megközelítőleg 1655-en részesültek biológiai terápiában, az arthritis psoriatica miatt biológiai terápián lévő betegeket nem számítva [17, 18]. Európában 2017-ben a következő biológiai gyógyszereket regisztrálták psoriasis kezelésére: infliximab, etanercept, adalimumab (mindhárom hatóanyagból originális és bioszimiláris is), ustekinumab, secukinumab, ixekizumab, brodalumab és guselkumab [19].

A biológiai gyógyszerek új korszakot jelentettek a pikkelysömörös betegek kezelését és életminőségét illetően. Magyarországon kiterjedt, a psoriasisos betegek életminőségét vizsgáló felmérés ez idáig nem történt, így nincsenek adatok a biológiai gyógyszerekkel kezelt betegek életminőségéról, a költséges terápiákkal elérhetô egészséghasznokról. Kutatásunk célja volt a hazai psoriasisos betegpopuláció életminőségének vizsgálata és összehasonlítása az általános populációval, illetve az életminőséget befolyásoló tényezők azonosítása. 


\section{Módszer}

\section{Keresztmetszeti kérdöines felmérés}

Kutatásunk két papíralapú, keresztmetszeti kérdőíves felmérésen alapul. Az első felmérésben 2012 szeptembere és 2013 májusa között a Semmelweis Egyetem Bör-, Nemikórtani és Bőronkológiai Klinikája és a Debreceni Egyetem Bőrgyógyászati Klinikája vett részt (etikai engedélyszám: ETT-TUKEB 35183/2012-EKU). A vizsgálatban középsúlyos vagy súlyos, járóbeteg-szakellátásban egymást követően megjelent psoriasisos betegek vehettek részt. A kutatás elsődleges célja a psoriasisban használt életminőség-mércék mérési tulajdonságainak elemzése, illetve a betegséggel összefüggő költségeinek felmérése volt. A kutatás eredményeit önállóan más közleményeinkben mutattuk be [20-23].

A második felmérést 2015 szeptembere és 2016 júniusa között a Semmelweis Egyetem Bőr-, Nemikórtani és Bőronkológiai Klinikáján végeztük (engedélyszám: Semmelweis Egyetem Regionális, Intézményi Tudományos és Kutatásetikai Bizottság 58/2015). A kérdőívet a járóbeteg- és fekvőbeteg-ellátásban jelentkező betegek egyaránt kitölthették, a psoriasis súlyosságától függetlenül. A kutatás elsődleges célja a DLQI validitásának és az EQ-5D-3L és EQ-5D-5L kérdőívek mérési tulajdonságainak összehasonlítása volt, mely eredményeket korábbi publikációinkban ismertettük [24-27].

Mindkét kérdőív két részből állt, az első részt a betegek töltötték ki, míg a második részben a betegek kezelőorvosai válaszoltak a kérdésekre. A betegek szociodemográfiai adatait, valamint általános és bőrgyógyászatspecifikus életminőségüket is felmértük. A kezelőorvosok a PASI segítségével értékelték a betegségsúlyosságot, emellett a klinikai típusokról, a betegségfennállási időről és az alkalmazott kezelés(ek)ról szolgáltattak adatokat. A kérdőívek kitöltése előtt minden beteg írásbeli beleegyező nyilatkozatot adott.

\section{A betegségsúlyosság és az életminőség mérése}

\section{$D L Q I$}

A Bőrgyógyászati Életminőség Index (DLQI) egy bőrgyógyászat-specifikus önkitöltős kérdőív, amely a leggyakrabban alkalmazott életminőség-mérce psoriasisban [28]. A tíz kérdésből álló kérdőív az alábbi részterületeket öleli fel: bőrtünetek miatti fájdalom, viszketés és feszélyezettség, hétköznapi tevékenységgel kapcsolatos teendők (vásárlás, takarítás, kertészkedés), öltözködés, társasági élet/szabadidős tevékenységek, sportolás, munka/tanulás, partnerrel/barátokkal való kapcsolattartás, szexuális élettel, kezeléssel kapcsolatos nehézségek. A kérdésekre adott válaszokat négyfokozatú skálán pontozzuk: „nagyon” - 3 pont, „meglehetősen” -2 pont, „kissé” - 1 pont és „egyáltalán nem” vagy „nem vonatkozik Önre" - 0 pont. A DLQI összpontszáma 0-tól 30-ig terjedő skálán értelmezhető, a magasabb érték rosszabb életminőséget jelez.

\section{PASI}

A PASI a pikkelysömör kiterjedését és súlyosságát vizsgáló mérce [29]. Amíg a PASI összesített, kezdeti értéke a terápia indítását határozza meg, addig a terápiára adott választ százalékos értékben fejezik ki (például PASI 25, PASI 50, PASI 75, PASI 90, PASI 100). A PASI 75 a páciens bőrtüneteinek 75\%-os javulását reprezentálja, a PASI 100 pedig a teljes remissziót jelenti. Kiszámításakor a test négy meghatározott régiója (fej, felső végtag, törzs, alsó végtag) az aktivitás szempontjából három nézőpontból (erythema, infiltráció, desquamatio) pontozható. Az aktivitási értékek (0: tünetmentes, 1: enyhe, 2: mérsékelt, 3: kifejezett, 4: súlyos), a kiterjedési értékek (0: 0\%, 1: <10\%, 2: 10-29\%, 3: 30-49\%, 4: 50-69\%, 5: 70-89\%, 6: 90-100\%) lehetnek. A PASI-pontszám kiszámításához az összaktivitást megszorozzuk a kiterjedési területtel, majd egy területspecifikus szorzóval (fej - 0,1, felső végtag - 0,2, törzs - 0,3, alsó végtag - 0,4). A végső pontérték 0 és 72 pont között változhat, ahol a magasabb pontszám súlyosabb állapotot jelöl [30].

\section{$E Q-5 D-3 L$}

A kutatásban az általános egészségi állapot mérésére az EQ-5D-3L-kérdőívet használtuk [31-33]. Az EQ-5D3L-kérdőív két részből áll. Első része egy leíró rendszer, amely az általános egészségi állapot öt dimenzióját (mozgékonyság, önellátás, szokásos tevékenységek, fájdalom/rossz közérzet, szorongás/lehangoltság) vizsgálja, mindegyik esetében három válaszlehetőség jelölhető meg ( 1 - nincs probléma, 2 - némi probléma, 3 - képtelen rá/súlyos probléma). Az így megkapott számsorokból (például 23212) hazai hasznossági súlyok hiányában az Egyesült Királyság hasznossági súlyait felhasználva számoltunk hasznosságértékeket (EQ-5D-3L-indexpontszám), amelyek -0,594-től 1-ig terjedő skálán értelmezhetők, ahol a magasabb érték jobb egészségi állapotra utal [34]. A kérdóív második része egy $20 \mathrm{~cm}$-es, függőlegesen elhelyezett Vizuális Analóg Skála, az EQ VAS. Az EQ VAS értéktartománya 0-tól 100-ig terjed, ahol a 0 az elképzelhető legrosszabb, a 100 pedig az elképzelhető legjobb egészségi állapotot jelöli [34].

\section{Statisztikai elemzések}

Elsőként leíró statisztikai elemzést végeztünk. Az életminőség-adatok (EQ-5D-3L-index-pontszám, EQ VAS és DLQI) ferde eloszlása miatt nem parametrikus MannWhitney-féle U- és Kruskal-Wallis-tesztet használtunk a betegek alcsoportjainak összehasonlítására. Az EQ-5D3L-index eredményeit a Baji és mtsai által közölt 2010- 
es hazai populációs normához hasonlítottuk [35]. Az életminőséget meghatározó tényezőket többváltozós lineáris regresszióval elemeztük. A heteroscedasticitas miatt Generalized Least Squares (GLS-) modellt használtunk mind a három életminőség-mérce esetében. Minden elemzésben 5\%-os szignifikanciaszintet használtunk. Az adatelemzéshez az SPSS 21.0 és a Gretl 1.9.4 programcsomagokat használtuk.

\section{Eredmények}

\section{A betegpopuláció jellemzôi}

Az első felmérésben 200, a másodikban pedig 238 psoriasisos beteg vett részt. Négy beteg mind a két felmérésben szerepelt, így az ő esetükben csak a későbbi kérdő- ívezésben adott válaszaikat vettük figyelembe. A teljes vizsgált betegpopuláció így 434 betegből állt, demográfiai és klinikai jellemzőiket az 1. táblázat mutatja be. A betegek 64,7\%-a férfi, az átlagéletkor 49,3 év (18-86 év) volt. Az összes beteg 86,2\%-a rendelkezett legalább középiskolai végzettséggel, a betegminta 29,3\%-a föiskolai/egyetemi diplomát szerzett. Foglalkoztatottság szempontjából a betegek közel fele $(47,7 \%)$ teljes munkaidőben dolgozott, 19,6\% nyugdíjas, 13,8\% rokkantnyugdíjas volt, valamint $8,3 \%$-ot részmunkaidőben foglalkoztattak.

A leggyakoribb klinikai típusok a krónikus plakkos psoriasis $(72,4 \%)$, a fejbőr- $(47,2 \%)$ és a körömpsoriasis $(44,7 \%)$, valamint az arthritis psoriatica $(35,5 \%)$ voltak. A bőrelváltozások elhelyezkedése szempontjából a lábon vagy lábszáron $(59,4 \%)$ és az alkaron $(50,9 \%)$ lévő bőr-

1. táblázat $\mid$ A betegpopuláció demográfiai és klinikai jellemzói $(n=434)$

\begin{tabular}{|c|c|c|c|}
\hline & \multicolumn{2}{|c|}{ Átlag (SD) vagy n (\%) } & \multirow[t]{2}{*}{ Átlag (SD) vagy $\mathrm{n}(\%)$} \\
\hline Nem & & A tünetek lokalizációja (hi & \\
\hline Nő & $153(35,3 \%)$ & Arc/homlok & $108(24,9 \%)$ \\
\hline Férfi & $281(64,7 \%)$ & Nyak/dekoltázs & $56(12,9 \%)$ \\
\hline Életkor (év) & $49,3(14,3)$ & Alkar & $221(50,9 \%)$ \\
\hline Iskolai végzettség & & Kéz & $155(35,7 \%)$ \\
\hline Alapfokú & $60(13,8 \%)$ & Kézkörmök & $141(32,5 \%)$ \\
\hline Középiskola/szakiskola & $247(56,9 \%)$ & Láb/lábszár & $258(59,4 \%)$ \\
\hline Főiskola/egyetem & $127(29,3 \%)$ & Terápia $^{\$}$ & \\
\hline Foglalkoztatottság & & Nem kap kezelést & $34(7,8 \%)$ \\
\hline Tanuló & $10(2,3 \%)$ & Csak lokális kezelés* & $104(24 \%)$ \\
\hline Teljes munkaidőben dolgozik & $207(47,7 \%)$ & Kalcipotriol & $7(1,6 \%)$ \\
\hline Részmunkaidőben dolgozik & $36(8,3 \%)$ & Ditranol & $3(0,7 \%)$ \\
\hline Munkanélküli & $19(4,4 \%)$ & Lokális szteroidkezelés & $81(18,7 \%)$ \\
\hline Nyugdíjas & $85(19,6 \%)$ & UVB & $13(3 \%)$ \\
\hline Rokkantnyugdíjas & $60(13,8 \%)$ & Egyéb & $24(5,5 \%)$ \\
\hline Egyéb & $26(6 \%)$ & PUVA & $4(0,9 \%)$ \\
\hline Betegségfennállási idő (év) & $19,9(12,2)$ & Szisztémás, nem biológiai* & $104(24 \%)$ \\
\hline Klinikai típusok & & Metotrexát & $77(17,7 \%)$ \\
\hline Krónikus plakkos & $314(72,4 \%)$ & Retinoid & $19(4,4 \%)$ \\
\hline Guttált & $27(6,2 \%)$ & Ciklosporin & $10(2,3 \%)$ \\
\hline Erythrodermás & $7(1,6 \%)$ & Biológiai terápia & $188(43,3 \%)$ \\
\hline Arcbőr és inverz tünetek & $79(18,2 \%)$ & Adalimumab & $66(15,2 \%)$ \\
\hline Fejbőr & $205(47,2 \%)$ & Etanercept & $46(10,6 \%)$ \\
\hline Tenyéri/talpi & $29(6,7 \%)$ & Infliximab & $41(9,4 \%)$ \\
\hline Köröm & $194(44,7 \%)$ & Ustekinumab & $35(8,1 \%)$ \\
\hline Arthritis psoriatica & $154(35,5 \%)$ & & \\
\hline Pustulosus & $2(0,5 \%)$ & & \\
\hline
\end{tabular}

\$Terápia a kérdőív kitöltésének időpontjában.

*Egy beteg többféle lokális és szisztémás, nem biológiai kezelést is kaphatott.

A klinikai típus, a lokalizáció és a terápia részeknél a betegekre több típus, tünet vagy kezelés is jellemző lehet, ezért haladja meg a százalékok összege a 100\%-ot ezekben a csoportosításokban. 


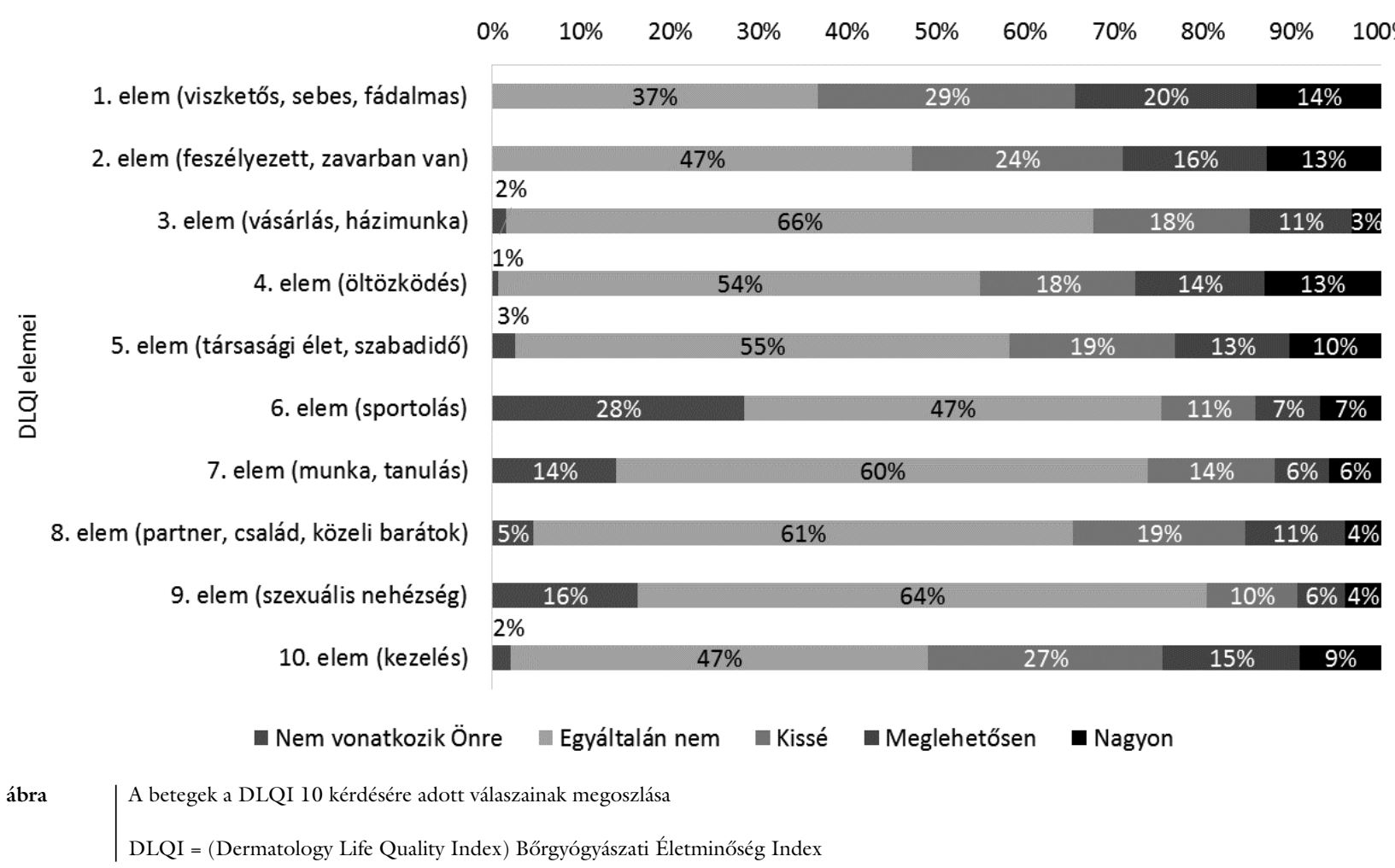

tünetek domináltak. Az átlagos betegségfennállási idő 19,9 év (SD: 12,2) volt. A kezeléseket tekintve lokális és szisztémás kezelésben is a betegek 24-24\%-a részesült, míg biológiai terápiát 43,3\% kapott a kérdőív kitöltésének idején.

\section{Életminôség-és betegségsúlyosság-eredmények}

Az EQ-5D-3L-index átlaga 0,74 (SD: 0,28) volt. A mintában összesen 17 (3,9\%) olyan beteg volt, aki negatív EQ-5D-3L-index-pontszámmal rendelkezett. Az EQ VAS-átlag 69,06 (SD: 20,98), a DLQI-átlag 6,78 (SD: $7,38)$ és a PASI átlaga 8,32 (SD: 9,50) volt.

A teljes mintát tekintve az EQ-5D-3L öt dimenziója közül a fájdalom/rossz közérzet, szorongás/lehangoltság, mozgékonyság, szokásos tevékenységek, önellátás dimenziókban rendre a betegek 54, 43, 40, 32, és 15 százaléka jelzett némi vagy súlyos problémát. A bőrtünet-specifikus életminőséget vizsgálva (DLQI) a legtöbb probléma a viszketős, sebes, fájdalmas bőr (63\%), a betegség miatti feszélyezettség (53\%), valamint a kezelés dimenziókban jelentkezett (51\%) (1. ábra). A legtöbb „nagyon” válasz a viszketős, sebes, fájdalmas bőr, betegség miatti feszélyezettség és zavar és az öltözködés dimenziókban fordult elő (13-14\%). A betegek a legkevesebb problémát a szexuális nehézség, a sportolás, a munka/tanulás, valamint a vásárlás/házimunka elvégzésének területein jelezték.

\section{Az általános életminöség összehasonlitása a magyar populációs normával}

A legnagyobb eltérést a psoriasisos betegek és az általános populáció életminősége között a szokásos tevékenységek és a mozgékonyság dimenziókban találtuk (2. ábra). Nemenkénti lakossági összehasonlításban (2. ábra) férfiaknál a szokásos tevékenységek dimenzióban volt a legnagyobb különbség (19\%) a hasonló korú férfilakossághoz képest, a mozgékonyság, az önellátás és a szorongás/lehangoltság dimenziókban kisebb különbséget láttunk $(9 \%, 12 \%$, illetve $10 \%)$, és a fájdalom/rossz közérzet mindössze 5\%-kal különbözött. Nőknél (2. ábra) ugyancsak a szokásos tevékenységek dimenziókban volt a legnagyobb különbség a hasonló korú lakossághoz képest (21\%), a mozgékonyság, az önellátás, a fájdalom/rossz közérzet és a szorongás/lehangoltság kevésbé volt érintett (a különbség rendre 17\%, 11\%, $18 \%$, illetve $15 \%)$.

A 2. táblázatban összehasonlítottuk a psoriasisban szenvedők EQ-5D-3L-indexszel mért életminőségét az általános populációéval nem és korcsoport szerinti bontásban. Megfigyelhető, hogy a betegek EQ-5D-3L-index-értéke az életkor növekedésével fokozatosan csökkent. A betegek életminősége minden korcsoportban rosszabb volt, mint a nemben és korban illesztett általános populációé, a különbség férfiaknál a 25-34 és 45-64 korcsoportokban, illetve nőknél a 18-64 éves korcsoportban volt statisztikailag szignifikáns $(\mathrm{p}<0,05)$. 
FÉRFIAK
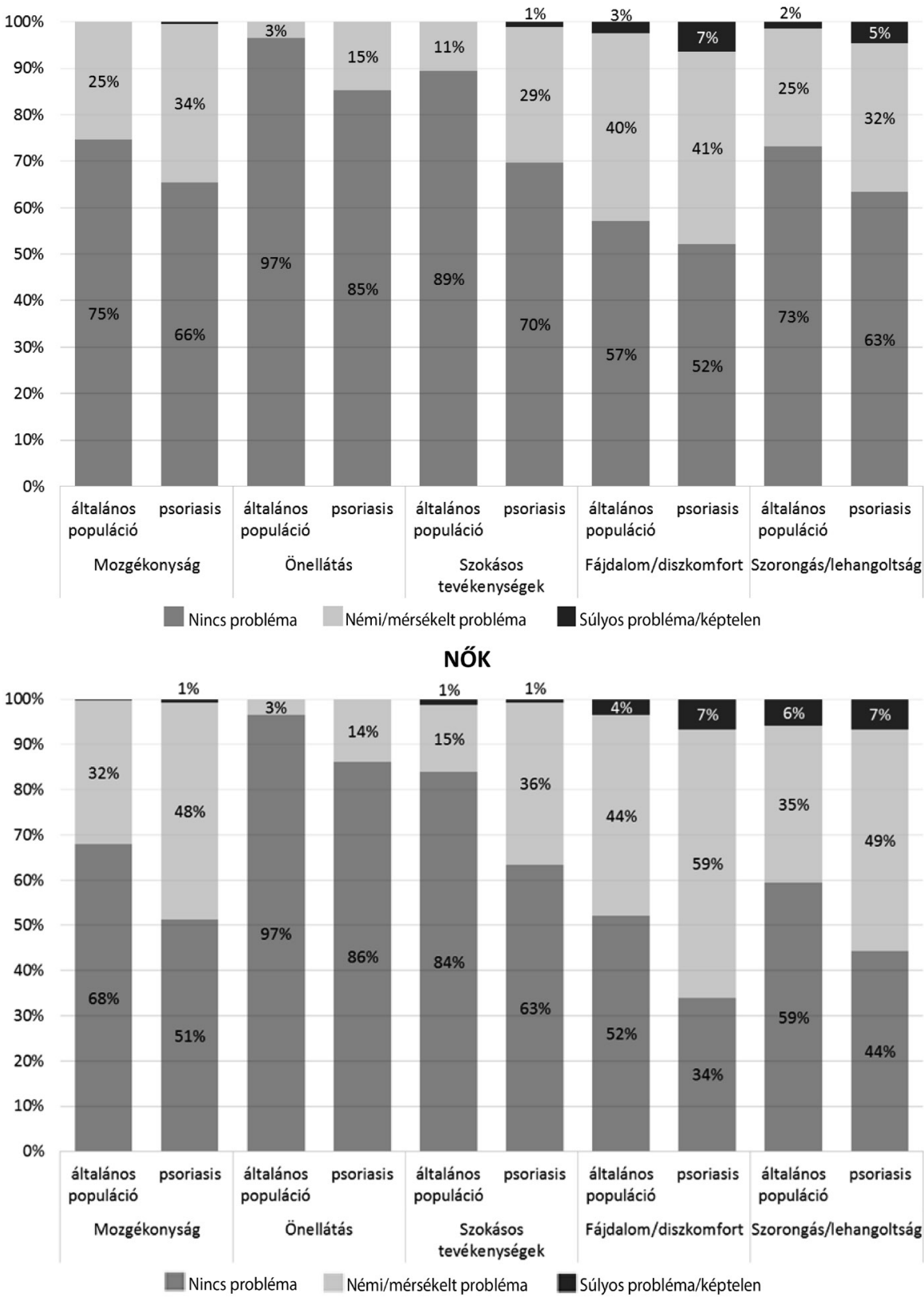

2. ábra A problémát jelzők aránya az EQ-5D-3L-kérdőív öt dimenziójában psoriasisos betegek és a nemben és életkorban illesztett magyar lakosság körében (45-54 év, férfiak, illetve nók esetén)

Az általános populáció adatainak forrása: Baji és mtsai [35]

\section{Az életminöséget befolyásoló tényező́k}

Az EQ-5D-3L-index, az EQ VAS és a DLQI pontszámait a betegek különböző alcsoportjaiban a 3. táblázat, az életminőséget magyarázó tényezők többváltozós elemzését a 4. táblázat mutatja be. Az EQ-5D-3L-indexszel mérve szignifikánsan rosszabb volt a súlyosabb betegek (magasabb PASI-pontszám), a nők, az arthritis psoriaticás és a tenyéri/talpi psoriasisos betegek életminősége. Jobb életminőséget találtunk a felsőfokú végzettségú és a rész- vagy teljes munkaidőben foglalkozta- tott betegeknél. Az EQ VAS-sal mérve szignifikánsan jobb volt a felsőfokú végzettségú és a rész- vagy teljes munkaidőben dolgozók általános életminősége, míg a súlyosabb betegek (magasabb PASI-pontszám), illetve a látható (ruhával nem fedett) testtájakon tüneteket mutatóké szignifikánsan rosszabb. A DLQI-val mért bőrgyógyászat-specifikus életminőség szignifikánsan csökkent a súlyosabb betegeknél (magasabb PASI-pontszám), az arthritis psoriatica, valamint a látható testtájakon jelentkező tünetek esetén. A biológiai terápia szignifikánsan javította a DLQI-val mért életminőséget. 
2. táblázat | Psoriasisos betegek EQ-5D-3L-index-pontszámai összehasonlítva a nemben és korban illesztett magyar lakossággal

\begin{tabular}{|c|c|c|c|c|c|c|c|c|c|c|}
\hline \multirow[t]{3}{*}{ Korcsoport (év) } & \multicolumn{5}{|c|}{ Férfiak } & \multicolumn{5}{|c|}{ Nők } \\
\hline & \multicolumn{2}{|c|}{ Psoriasis } & \multicolumn{2}{|c|}{ Általános populáció } & \multirow[t]{2}{*}{ p-érték* } & \multicolumn{2}{|c|}{ Psoriasis } & \multicolumn{2}{|c|}{ Általános populáció } & \multirow[t]{2}{*}{ p-érték* } \\
\hline & $\mathrm{n}$ & Átlag (SD) & $\mathrm{n}$ & Átlag (SD) & & $\mathrm{n}$ & Átlag (SD) & $\mathrm{n}$ & Átlag (SD) & \\
\hline $18-24$ & 11 & $0,85(0,13)$ & 90 & $0,91(0,14)$ & 0,1064 & 8 & $0,64(0,33)$ & 207 & $0,89(0,16)$ & 0,0326 \\
\hline $25-34$ & 40 & $0,78(0,28)$ & 190 & $0,94(0,13)$ & 0,0005 & 18 & $0,74(0,25)$ & 376 & $0,88(0,15)$ & 0,0148 \\
\hline $35-44$ & 60 & $0,84(0,26)$ & 183 & $0,88(0,20)$ & 0,3674 & 29 & $0,73(0,29)$ & 315 & $0,85(0,19)$ & 0,0205 \\
\hline $45-54$ & 61 & $0,76(0,29)$ & 198 & $0,84(0,20)$ & 0,0499 & 28 & $0,66(0,29)$ & 311 & $0,79(0,25)$ & 0,0268 \\
\hline $55-64$ & 66 & $0,67(0,32)$ & 155 & $0,81(0,23)$ & 0,0012 & 37 & $0,67(0,28)$ & 182 & $0,78(0,25)$ & 0,0292 \\
\hline $65+$ & 38 & $0,75(0,27)$ & 43 & $0,84(0,22)$ & 0,0906 & 29 & $0,70(0,23)$ & 31 & $0,77(0,18)$ & 0,1917 \\
\hline
\end{tabular}

*A dôlt értékek statisztikailag szignifikáns különbséget jelölnek $(\mathrm{p}<0,05)$.

Az általános populáció adatainak forrása: Baji és mtsai [35].

3. táblázat | EQ-5D-3L-, EQ-VAS- és DLQI-pontszámok a betegek alcsoportjaiban

\begin{tabular}{|c|c|c|c|c|c|c|}
\hline & \multicolumn{2}{|c|}{ EQ-5D-3L } & \multicolumn{2}{|c|}{ EQ VAS } & \multicolumn{2}{|c|}{ DLQI } \\
\hline & $\mathrm{n}$ & Átlag (SD) & $\mathrm{n}$ & Átlag (SD) & $\mathrm{n}$ & Átlag (SD) \\
\hline Teljes minta & 425 & $0,74(0,28)$ & 430 & $69,06(20,98)$ & 428 & $6,78(7,38)$ \\
\hline \multicolumn{7}{|l|}{$\mathrm{Nem}$} \\
\hline Nő & 149 & $0,69(0,27)^{*}$ & 151 & $68,52(20,72)$ & 150 & $7,61(7,60)$ \\
\hline Férfi & 276 & $0,76(0,29)^{*}$ & 279 & $69,35(21,15)$ & 278 & $6,33(7,23)$ \\
\hline \multicolumn{7}{|l|}{ Klinikai tipus } \\
\hline Krónikus plakkos & 310 & $0,71(0,29)^{*}$ & 314 & $67,14(20,50)^{*}$ & 314 & $8,12(7,24)^{*}$ \\
\hline Guttált & 27 & $0,71(0,27)$ & 27 & $66,37(19,55)$ & 27 & $8,52(6,99)^{*}$ \\
\hline Erythrodermás & 7 & $0,55(0,35)$ & 7 & $47,00(22,13) *$ & 7 & $14,86(9,06)^{*}$ \\
\hline Arcbőr és inverz tünetek & 78 & $0,73(0,25)$ & 78 & $65,23(21,38)$ & 78 & $11,10(7,77)^{*}$ \\
\hline Fejbőr & 203 & $0,70(0,27)^{*}$ & 205 & $65,20(20,35)^{*}$ & 205 & $10,64(7,42)^{*}$ \\
\hline Tenyéri/talpi & 29 & $0,55(0,33)^{*}$ & 29 & $60,79(22,97)^{*}$ & 29 & $10,62(6,69)^{*}$ \\
\hline Körömérintettség & 191 & $0,69(0,29)^{*}$ & 194 & $66,06(20,59)^{*}$ & 194 & $8,96(7,55)^{*}$ \\
\hline Arthritis psoriatica & 153 & $0,60(0,31)^{*}$ & 154 & $62,87(20,96)^{*}$ & 154 & $9,19(7,90)^{*}$ \\
\hline Pustulosus & 2 & $0,36(0,57)$ & 2 & $82,50(10,61)$ & 2 & $4,50(3,53)$ \\
\hline \multicolumn{7}{|l|}{ Tünetek a ruhával nem fedett testtájakon ** } \\
\hline Igen & 272 & $0,68(0,30)^{*}$ & 275 & $64,77(21,30)^{*}$ & 275 & $9,04(7,53)^{*}$ \\
\hline Nem & 126 & $0,85(0,21)^{*}$ & 128 & $76,64(18,85)^{*}$ & 126 & $2,17(4,60)^{*}$ \\
\hline \multicolumn{7}{|l|}{ Kezelések } \\
\hline Nem kap kezelést & 31 & $0,68(0,28)$ & 31 & $60,81(23,08)^{*}$ & 31 & $12,10(8,34)^{*}$ \\
\hline Csak lokális kezelés & 103 & $0,70(0,29)$ & 103 & $65,48(20,27)^{*}$ & 103 & $10,99(7,13)^{*}$ \\
\hline Szisztémás, nem biológiai vagy PUVA & 104 & $0,67(0,29)^{*}$ & 108 & $65,70(18,34)^{*}$ & 107 & $8,42(7,38)^{*}$ \\
\hline Biológiai & 187 & $0,80(0,27)^{*}$ & 188 & $74,31(21,33)^{*}$ & 187 & $2,64(4,62)^{*}$ \\
\hline
\end{tabular}

*Ahol az alcsoport átlagértéke szignifikánsan különbözött a minta másik részétől $(\mathrm{p}<0,05)$.

* *Ruhával nem fedett testtájak: fejbőr, arc, nyak/dekoltázs, alkar, kéz, kézkörmök.

\section{Megbeszélés}

Kutatásunkban két hazai egyetemi bórgyógyászati klinika több mint 400 psoriasisos betegének bevonásával végzett vizsgálat együttes elemzését végeztük el. Ismereteink szerint ez az első kiterjedt életminőség-felmérés pikkelysömörös betegek körében Magyarországon és egész Közép-Kelet-Európában, ahol a bőrgyógyászatspecifikus DLQI mellett az EQ-5D-3L-kérdő́iv segítségével hasznosságértékeket számoltunk. A betegek általános életminőségét a magyar populációs normával hasonlítottuk össze, illetve azonosítottuk az életminőséget befolyásoló tényezóket. Mintánkban összesen 188 beteg részesült biológiai kezelésben, tehát kutatásunk a 
4. táblázat |Az életminőséget befolyásoló tényezők többváltozós regressziós elemzése (GLS-modellek)

\begin{tabular}{|c|c|c|c|c|c|c|c|c|c|}
\hline & \multicolumn{3}{|l|}{ EQ-5D-3L } & \multicolumn{3}{|l|}{ EQ VAS } & \multicolumn{3}{|l|}{ DLQI } \\
\hline & $\begin{array}{l}\text { Regressziós } \\
\text { koefficiens }\end{array}$ & $\begin{array}{l}\text { Standard } \\
\text { hiba }\end{array}$ & p-érték & $\begin{array}{l}\text { Regressziós } \\
\text { koefficiens }\end{array}$ & $\begin{array}{l}\text { Standard } \\
\text { hiba }\end{array}$ & p-érték & $\begin{array}{l}\text { Regressziós } \\
\text { koefficiens }\end{array}$ & $\begin{array}{l}\text { Standard } \\
\text { hiba }\end{array}$ & p-érték \\
\hline Konstans & 0,806 & 0,025 & $<0,0001$ & 72,212 & 2,059 & $<0,0001$ & 2,207 & 0,500 & $<0,0001$ \\
\hline Nem (nő) & $-0,045$ & 0,022 & 0,0420 & - & - & - & - & - & - \\
\hline Felsőfokú végzettség & 0,075 & 0,021 & 0,0004 & 4,902 & 2,027 & 0,0161 & - & - & - \\
\hline $\begin{array}{l}\text { Rész- vagy teljes } \\
\text { munkaidőben dolgozik }\end{array}$ & 0,084 & 0,023 & 0,0003 & 7,607 & 1,967 & 0,0001 & - & - & - \\
\hline PASI-pontszám & $-0,006$ & 0,001 & $<0,0001$ & $-0,650$ & 0,114 & $<0,0001$ & 0,411 & 0,039 & $<0,0001$ \\
\hline Arthritis psoriatica & $-0,155$ & 0,024 & $<0,0001$ & - & - & - & 1,538 & 0,372 & $<0,0001$ \\
\hline Tenyéri/talpi psoriasis & $-0,140$ & 0,065 & 0,0309 & - & - & - & - & - & - \\
\hline $\begin{array}{l}\text { Tünetek a ruhával nem } \\
\text { fedett testtájakon* }\end{array}$ & - & - & - & $-5,383$ & 2,123 & 0,0116 & 1,429 & 0,427 & 0,0009 \\
\hline Biológiai terápia & - & - & - & - & - & - & $-2,089$ & 0,498 & $<0,0001$ \\
\hline $\mathrm{n}$ & \multicolumn{3}{|c|}{425} & \multicolumn{3}{|c|}{403} & \multicolumn{3}{|c|}{401} \\
\hline F-próba & \multicolumn{3}{|c|}{$\mathrm{F}(6,418)=27,01$} & \multicolumn{3}{|c|}{$\mathrm{F}(4,398)=26,29$} & \multicolumn{3}{|c|}{$\mathrm{F}(4,396)=78,55$} \\
\hline p-érték & \multicolumn{3}{|c|}{$<0,0001$} & \multicolumn{3}{|c|}{$<0,0001$} & \multicolumn{3}{|c|}{$<0,0001$} \\
\hline $\mathrm{R}^{2}$ & \multicolumn{3}{|c|}{0,28} & \multicolumn{3}{|c|}{0,21} & \multicolumn{3}{|c|}{0,44} \\
\hline
\end{tabular}

*Ruhával nem fedett testtájak: fejbőr, arc, nyak/dekoltázs, alkar, kéz, kézkörmök.

teljes hazai biológiai terápián lévő psoriasisos betegpopuláció több mint 10\%-át elérte [18]. Eredményeink rámutatnak, hogy a psoriasisos betegek életminősége roszszabb az általános populációénál, különösen a szokásos tevékenységek területén (2. ábra), emellett alátámasztják a biológiai terápia életminőséget is javító hatását (4. táblázat). Azonosítottuk azokat a fóbb demográfiai és klinikai tényezőket (például magasabb PASI-pontszám, arthritis psoriatica megléte, látható bőrtünetek, tenyéri/talpi psoriasis, nói nem), amelyek negatívan befolyásolják az életminőséget, illetve amelyek fontos beavatkozási pontok lehetnek a klinikai gyakorlatban.

Számos közleményt találhatunk a nemzetközi szakirodalomban, amelyekben psoriasisos betegek életminőségét vizsgálták az EQ-5D-3L-kérdőívvel, döntően randomizált kontrollált vizsgálatokban. A vizsgált mintanagyság többnyire 100 és 200 között változott, így a kutatásunkban elemzett 434 fös egyesített minta nemzetközi összehasonlításban is magasnak mondható. Ezekben a vizsgálatokban az EQ-5D-index-értékeket, jelen kutatásunkhoz hasonlóan, a legtöbbször az Egyesült Királyságból származó hasznosságsúlyok használatával számolták ki, a kiindulási átlagos értékek 0,50-tól 0,82-ig terjedtek [36]. Felmérésünkben a nem kezelt, illetve a biológiai kezelésben részesülő betegek alcsoportjaiban hasonló eredményre jutottunk $(0,68$, illetve 0,80$)$. Fontosnak tartjuk azonban hangsúlyozni, hogy a különböző országokban és vizsgálatokban gyújtött EQ-5D-index-eredmények közvetlen összehasonlítása óvatosságot igényel. $\mathrm{Az}$ EQ-5D-eredmények eltéréseit okozhatják a betegpopulációk különbségei (például a betegségsúlyosság és a biológiai terápiában részesülők aránya) és az is, ha különböző hasznosság-értékkészleteket alkalmaznak az EQ-5D-index kiszámolásához.

Magyarországon korábban számos krónikus betegségben végeztek már EQ-5D-3L-lel vizsgálatokat, melyekből kiemelnénk a Brodszky és mtsai által 2008-ban végzett felmérést arthritis psoriaticában. A betegek 6\%-a részesült biológiai terápiában, és az átlagos EQ-5D-index-érték alacsonyabb volt, mint a jelen mintánk arthritis psoriaticás alcsoportjában $(0,47$ SD: 0,35 versus 0,60 SD: 0,31$)[33,37]$. Fontos megjegyezni, hogy a psoriasis nemcsak arthritis psoriaticával társulhat, hanem más immunmediált kórképekkel is, melyek a betegség jelentôs pszichológiai terhét tovább fokozzák [38, 39].

A pustulosus, erythrodermás, tenyéri/talpi psoriasisos és arthritis psoriaticában szenvedőknél mértük a legroszszabb általános életminőséget, ezen betegcsoportok ellátása fokozott figyelmet érdemel. Kiemelkedően rossz volt még a látható testtájakon lévő bőrtüneteket mutató betegek életminősége, a ruhával nem fedett testtájakon található tünetek sokszor stigmatizálják a betegeket, ami a mentális egészséggel kapcsolatos problémákhoz vezethet, illetve nehezítheti a társadalmi beilleszkedést [40]. Az optimális terápia megválasztásakor ezért indokolttá vált számításba venni a bőrtünetek lokalizációját, hogy a lehető legnagyobb egészségnyereséget érjük el egy-egy betegnél [15].

Figyelemre méltó eredmény, hogy a rész- vagy teljes munkaidőben foglalkoztatott betegeknél szignifikánsan jobb életminőséget találtunk. A krónikus bőrgyógyászati betegek, így a psoriasisos betegek munkaerópiaci elhe- 
lyezkedésének és munkahelyük megtartásának támogatása fontos célok lehetnek az egészséggel összefüggó életminőség javulásának szempontjából is.

A jelen kutatásban felmért EQ-5D-3L-eredmények jelentősen hozzájárulnak az egészségpolitikai és finanszírozói döntéshozatalhoz. Az EQ-5D-3L-adatok fontos hasznosítási területe az egészségügyi közgazdaságtan. Kutatásunk elsőként nyújt hazai, psoriasisos betegeken mért hasznosságértékeket, amelyek alkalmasak a psoriasis terápiáinak költséghatékonysági modellezésére, ezáltal javíthatják a hazai egészségpolitikai döntés-előkészítést $[41,42]$.

Kutatásunk korlátai között kiemelendő, hogy a vizsgált betegcsoport nem tekinthető reprezentatívnak a psoriasisban szenvedő hazai betegpopuláció egészére. A betegtoborzás két egyetemi klinika részvételével történt, ebből kifolyólag mintánkban vélhetően felülreprezentált a középsúlyos vagy súlyos psoriasisos betegek száma, illetve a biológiai terápiában részesülők aránya. Életminőség-eredményeink tehát nem a kezeletlen psoriasis betegségterhét mutatják, hanem egy kezelés alatt álló, többségében középsúlyos vagy súlyos betegpopulációét. A bőrbetegség-specifikus életminőség mérésére a DLQIkérdőívet használtuk, azonban az utóbbi évek kutatásai alapján e mérce validitása psoriasisban kérdésessé vált [24, 26, 27, 43-47].

Eissing és munkatársainak 2015. októberben zárult szisztematikus szakirodalmi áttekintése összesen 14 psoriasis-betegregisztert azonosított, többségben nyugateurópai országokból (Ausztria, Dánia, Amerikai Egyesült Államok, Egyesült Királyság, Hollandia, Írország, Malajzia, Németország, Olaszország, Spanyolország, Svédország, illetve nemzetközi regiszterek) [48]. Ezekben az életminőséget a leggyakrabban (8 regiszter) a DLQI-kérdőívvel mérték, 4 regiszterben az EQ-5D-kérdőívvel párhuzamosan. Nemrégiben a közép-európai régióban a Cseh Köztársaság BIOREP-regiszteréból közöltek életminőség-eredményeket DLQI alapján [49]. Hazánkban egy psoriasis-betegregiszter létrehozása hasznos jövőbeli cél lenne, melyben hosszú távon is követni tudnánk a betegek egészségi állapotát és életminőségét [50]. Szisztematikus adatgyújtéssel pontosabb képet kaphatnánk a terápiák biztonságosságáról, valós hasznáról, a terápiás választ meghatározó tényezőkről és a gondozás minőségéről.

Anyagi támogatás: A közlemény megírása és a kapcsolódó kutatómunka anyagi támogatásban nem részesültt.

Szerzői munkamegosztás: P. A. K., B. V., P. M., G. L., R. F. megtervezték a kutatást és kidolgozták a hipotéziseket. P. A. K., R. É., Sz. A., H. P. részt vettek a betegtoborzásban és a vizsgálat lefolytatásában. Cs. T., B. V., R. F. végezték el a számolásokat és statisztikai elemzéseket. P. A. K., Cs. T., P. M., R. F. részt vettek a kézirat megírásában. B. V., G. L., R. É., Sz. A., H. P., S. M. kritikai észrevételeikkel hozzájárultak a kézirat közlésre történő előkészítéséhez. A cikk végleges változatát valamennyi szerző elolvasta, hozzászólt és jóváhagyta.

Érdekeltségek: A szerzőknek nincsenek érdekeltségeik.

\section{Köszönetnyilvánítás}

Cserni Tamás az Emberi Erőforrások Minisztériuma Új Nemzeti Kiválóság Programjának ösztöndíjas hallgatójaként vett részt a kutatásban (ÚNKP-17-2-II-BCE-38). A szerzők köszönetüket fejezik ki a két kérdőíves vizsgálatban közremúködő kollégáknak és betegeknek.

\section{Irodalom}

[1] Michalek IM, Loring B, John SM. A systematic review of worldwide epidemiology of psoriasis. J Eur Acad Dermatol Venereol. 2017; 31: 205-212.

[2] Parisi R, Symmons DP, Griffiths CE, et al. Global epidemiology of psoriasis: a systematic review of incidence and prevalence. $\mathrm{J}$ Invest Dermatol. 2013; 133: 377-385.

[3] Greb JE, Goldminz AM, Elder JT, et al. Psoriasis. Nat Rev Dis Primers 2016; 2: 16082

[4] Péter I, Jagicza A, Ajtay Z, et al. Psoriasis and oxidative stress. [A psoriasis és az oxidatív stressz.] Orv Hetil. 2016; 157: 17811785. [Hungarian]

[5] Boehncke WH, Schön MP. Psoriasis. Lancet 2015; 386: 983994.

[6] Weger W. An update on the diagnosis and management of psoriatic arthritis. G Ital Dermatol Venereol. 2011; 146: 1-8.

[7] Ahmed N, Prior JA, Chen Y, et al. Prevalence of cardiovascularrelated comorbidity in ankylosing spondylitis, psoriatic arthritis and psoriasis in primary care: a matched retrospective cohort study. Clin Rheumatol. 2016; 35: 3069-3073.

[8] Frieder J, Ryan C. Psoriasis and cardiovascular disorders. G Ital Dermatol Venereol. 2016; 151: 678-693.

[9] Gelfand JM. Psoriasis, Type 2 diabetes mellitus, and obesity: weighing the evidence. JAMA Dermatol. 2016; 152: 753-754.

[10] van der Voort EA, Wakkee M, Veldt-Kok P, et al. Enhanced liver fibrosis test in patients with psoriasis, psoriatic arthritis and rheumatoid arthritis: a cross-sectional comparison with procollagen-3 N-terminal peptide (P3NP). Br J Dermatol. 2017; 176: 15991606.

[11] Gonzalez J, Cunningham K, Perlmutter J, et al. Systematic review of health-related quality of life in adolescents with psoriasis. Dermatology 2016; 232: 541-549.

[12] Kálmán LJ, Gonda X, Kemény L, et al. Psychological and biological background of the interaction between psoriasis and stress. [A pikkelysömör és a stressz közötti összefüggés pszichológiai és biológiai alapjai.] Orv Hetil. 2014; 155: 939-948. [Hungarian].

[13] van Beugen S, van Middendorp H, Ferwerda M, et al. Predictors of perceived stigmatization in patients with psoriasis. Br J Dermatol. 2017; 176: 687-694.

[14] Mrowietz U, Kragballe K, Reich K, et al. Definition of treatment goals for moderate to severe psoriasis: a European consensus. Arch Dermatol Res. 2011; 303: 1-10.

[15] Nast A, Gisondi P, Ormerod AD, et al. European S3-Guidelines on the systemic treatment of psoriasis vulgaris - Update 2015 EDF in cooperation with EADV and IPC. J Eur Acad Dermatol Venereol. 2015; 29: 2277-2294.

[16] National Health Insurance Fund Administration of Hungary, Department of Medical Expertise, Clinical Auditing and Analysis. Financing protocol on diagnosis and treatment of plaque psoriasis. [Országos Egészségbiztosítási Pénztár, Elemzési, Orvosszakértői és Szakmai Ellenőrzési Főosztály. A plakkos pso- 
riasis diagnosztikájának és kezelésének finanszírozási protokollja (eljárásrend)]. Budapest, 2013. Available from: http://www. neak.gov.hu/data/cms989739/0626_a_plakkos_psoriasis_diagnosztikajanak_es_kezelesenek_finanszirozasi_protokollja.pdf [accessed: November 4, 2017]. [Hungarian]

[17] Rencz F, Kemény L, Gajdácsi JZ, et al. Use of biologics for psoriasis in Central and Eastern European countries. J Eur Acad Dermatol Venereol. 2015; 29: 2222-2230.

[18] Zrubka Z. Economic aspects of biosimilar competition in Hungary - The treatment of rheumatic disorders. Society and Economy 2017; 39: 271-290.

[19] European Medicines Agency. Find medicine/Human medicines/Keyword search: Psoriasis, Therapeutic indication. 2017. http://www.ema.europa.eu/ema/ [assessed: November 27, 2017].

[20] Balogh O, Brodszky V, Gulácsi L, et al. Cost-of-illness in patients with moderate to severe psoriasis: a cross-sectional survey in Hungarian dermatological centres. Eur J Health Econ. 2014; 1(Suppl 1): S101-S109.

[21] Herédi E, Rencz F, Balogh O, et al. Exploring the relationship between EQ-5D, DLQI and PASI, and mapping EQ-5D utilities: a cross-sectional study in psoriasis from Hungary. Eur J Health Econ. 2014; 15(Suppl 1): S111-S119.

[22] Rencz F, Brodszky V, Péntek M, et al. Disease burden of psoriasis associated with psoriatic arthritis in Hungary. [Arthritis psoriaticával társuló középsúlyos és súlyos psoriasis betegségterhe Magyarországon.] Orv Hetil. 2014; 155: 1913-1921. [Hungarian]

[23] Rencz F, Holló P, Kárpáti S, et al. Moderate to severe psoriasis patients' subjective future expectations regarding health-related quality of life and longevity. J Eur Acad Dermatol Venereol. 2015; 29: 1398-1405.

[24] Poór AK, Brodszky V, Péntek M, et al. Is the DLQI appropriate for medical decision-making in psoriasis patients? Arch Dermatol Res. 2018; 310: 47-55.

[25] Poór AK, Rencz F, Brodszky V, et al. Measurement properties of the EQ-5D-5L compared to the EQ-5D-3L in psoriasis patients. Qual Life Res. 2017; 26: 3409-3419.

[26] Rencz F, Baji P, Gulácsi L, et al. Discrepancies between the Dermatology Life Quality Index and utility scores. Qual Life Res. 2016; 25: 1687-1696.

[27] Rencz F, Poór AK, Péntek M, et al. A detailed analysis of 'not relevant' responses on the DLQI in psoriasis: potential biases in treatment decisions. J Eur Acad Dermatol Venereol. 2017 Nov 8. doi: $10.1111 /$ jdv.14676. [Epub ahead of print]

[28] Finlay AY, Khan GK. Dermatology Life Quality Index (DLQI) - a simple practical measure for routine clinical use. Clin Exp Dermatol. 1994; 19: 210-216.

[29] Fredriksson T, Pettersson U. Severe psoriasis - oral therapy with a new retinoid. Dermatologica 1978; 157: 238-244.

[30] Feldman S, Krueger G. Psoriasis assessment tools in clinical trials. Ann Rheum Dis. 2005; 64: ii65-ii68.

[31] EuroQol - a new facility for the measurement of health-related quality of life. Health Policy 1990; 16: 199-208.

[32] Brooks R. EuroQol: the current state of play. Health Policy 1996; 37: 53-72.

[33] Rencz F, Gulácsi L, Drummond M, et al. EQ-5D in Central and Eastern Europe: 2000-2015. Qual Life Res. 2016; 25: 26932710.

[34] Dolan P. Modeling valuations for EuroQol health states. Med Care 1997; 35: 1095-1108.
[35] Baji P, Brodszky V, Rencz F, et al. Health status of the Hungarian population between 2000-2010. [A magyar lakosság egészségi állapota 2000 és 2010 között.] Orv Hetil. 2015; 156: 2035-2044. [Hungarian].

[36] Yang Y, Brazier J Longworth L. EQ-5D in skin conditions: an assessment of validity and responsiveness. Eur J Health Econ. 2015; 16: 927-939.

[37] Brodszky V, Péntek M, Bálint PV, et al. Comparison of the Psoriatic Arthritis Quality of Life (PsAQoL) questionnaire, the functional status (HAQ) and utility (EQ-5D) measures in psoriatic arthritis: results from a cross-sectional survey. Scand J Rheumatol. 2010; 39: 303-309.

[38] Bazsó A, Szodoray P, Szappanos A, et al. Systemic autoimmune, rheumatic diseases and coinciding psoriasis: data from a large single-centre registry and review of the literature. Mediators Inflamm. 2015; 2015: 657907.

[39] Dalgard FJ, Gieler U, Tomas-Aragones L, et al. The psychological burden of skin diseases: a cross-sectional multicenter study among dermatological out-patients in 13 European countries. J Invest Dermatol. 2015; 135: 984-991.

[40] Hrehorow E, Salomon J, Matusiak L, et al. Patients with psoriasis feel stigmatized. Acta Derm Venereol. 2012; 92: 67-72.

[41] Boncz I, Sebestyén A. Financial deficits in the health services of the UK and Hungary. Lancet 2006; 368: 917-918.

[42] Gulácsi L, Rencz F, Poór G, et al. Patients' access to biological therapy in chronic inflammatory conditions; per capita GDP does not explain the intercountry differences. Ann Rheum Dis. 2016; 75: 942-943.

[43] He Z, Lo Martire R, Lu C, et al. Rasch analysis of the Dermatology Life Quality Index reveals limited application to Chinese patients with skin disease. Acta Derm Venereol. 2018; 98: 5964.

[44] Liu Y, Li T, An J, et al. Rasch analysis holds no brief for the use of the Dermatology Life Quality Index (DLQI) in Chinese neurodermatitis patients. Health Qual Life Outcomes 2016; 14: 17.

[45] Nijsten T. Dermatology Life Quality Index: time to move forward. J Invest Dermatol. 2012; 132: 11-13.

[46] Nijsten T, Meads DM, de Korte J, et al. Cross-cultural inequivalence of dermatology-specific health-related quality of life instruments in psoriasis patients. J Invest Dermatol. 2007; 127: 23152322 .

[47] Nijsten T, Meads DM, McKenna SP. Dimensionality of the Dermatology Life Quality Index (DLQI): a commentary. Acta Derm Venereol. 2006; 86: 284-285; author reply 285-286.

[48] Eissing L, Rustenbach SJ, Krensel M, et al. Psoriasis registries worldwide: systematic overview on registry publications. J Eur Acad Dermatol Venereol. 2016; 30: 1100-1106.

[49] Kojanova M, Fialova J, Cetkovska P, et al. Characteristics and risk profile of psoriasis patients included in the Czech national registry BIOREP and a comparison with other registries. Int J Dermatol. 2017; 56: 428-434.

[50] Rencz F. Patients with psoriasis on a new trajectory: long-term improvement in quality of life with biologics. Br J Dermatol. 2018; 178: 29-30

(Péntek Márta dr., Budapest, Fővám tér 8., 1093 e-mail: marta.pentek@uni-corvinus.hu) feltéve, hogy az eredeti szerző és a közlés helye, illetve a CC License linkje és az esetlegesen végrehajtott módosítások feltüntetésre kerülnek. 